\title{
Integration of Multicultural Values Based on Sundanese Local Wisdom (Silih Asah, Silih Asih, Silih Asuh) in History Learning in The Era of Globalization
}

\author{
Sarip Hidayatuloh \\ Universitas Sebelas Maret \\ sariphidayatuloh111@gmail.com
}

\section{Article History}

accepted 1/09/2020

\author{
approved 4/10/2020
}

published $1 / 12 / 2020$

\begin{abstract}
The flow of golbalization which continues to experience development has changed the order of life of the people, which has made it increasingly lose our identity and the more fragile our spirit of diversity as a nation. Local wisdom is a characteristic of the nation that must be preserved. The integration of multicultural values based on local wisdom in historical learning in the era of a global perspective is how the role of a teacher in making students aware of tolerance, cooperation, love, respect, nationalism and so on, without leaving local wisdom values. exist in society. This study uses a qualitative method with a library research approach. The concept of silih asah, silih asih, silih asuh is a concept of harmony in Sundanese life. These three concepts are used as a philosophy of life that is adhered to by the majority of Sundanese people. Multicultural value education based on local wisdom from a global perspective, can be a means of cultivating and implementing good and correct character of the Indonesian nation by educating and teaching Sundanese local wisdom values (silih asah, silih asih, silih asuh).

Keywords : Multicultural value, local genius, silih asah, silih asih, silih asuh
\end{abstract}

\begin{abstract}
Abstrak
Arus golbalisasi yang terus mengalami perkembangan telah banyak mengubah tatanan kehidupan masyrakat, yang membuatnya semakin kehilangan identitas/jati diri dan semakin rapuhnya semangat keberagaman kita sebagai suatu nationa. Kearifan lokal merupakan ciri khas bangsa yang harus dilestarikan. Integrasi nilai multicultural berbasis kearifan lokal dalam pembelajaran sejarah di era perspektif global adalah bagaimana peran seorang guru dalam menyadarkan peserta didik untuk terus menjunjung tinggi toleransi, kerja sama, mengasihi, hormat-menghormati, rasa kebangsaan dan sebagainya, tanpa meninggalkan nilai-nilai kearifan lokal yang ada dalam masyarakat. Penelitian ini menggunakan metode kualitatif dengan pendekatan studi kepustakaan atau library research. Konsep silih asah, silih asih, silih asuh merupakan konsep kerukunan hidup masyarakat Sunda. Ketiga konsep tersebut digunakan sebagai falsafah hidup yang dianut mayoritas masyarakat Sunda. Pendidikan nilai multicultural berbasis kearifan lokal dalam perspektif global, dapat menjadi sarana dalam penanaman dan implementasi karakter bangsa Indonesia yang baik dan benar dengan mendidik dan mengajarkan nilai kearifan local Sunda (silih asah, silih asih, silih asuh).
\end{abstract}

Kata Kunci: Nilai multikultural, kearifan lokal, silih asah, silih asih, silih asu

Social, Humanities, and Education Studies (SHEs): Conference Series https://jurnal.uns.ac.id/shes

p-ISSN 2620-9284

e-ISSN 2620-9292 


\section{PENDAHULUAN}

Perkembangan teknologi yang begitu pesat telah menciptakan gelombang informasi yang dapat diakses secara mudah, cepat, dan murah. Informasi yang berkembang menjadi sulit dibendung dan dikontrol. Tidak bisa dipungkiri memang, perkembangan teknologi telah memberikan banyak manfaat dalam berbagai aspek kehidupan, dan secara bersamaan perkembangan teknologi juga memberikan dampak yang amat buruk.

Adam (2017) mengungkapkan bahwa generasi yang sudah mengenal internet dapat memengaruhi karakternya. Generasi Z misalnya, memiliki keunggulan lebih peka terhadap pergaulan global, memiliki pikiran yang lebih terbuka, lebih cepat terjun ke dalam dunia kerja, memiliki jiwa wirausaha, dan lebih ramah terhadap teknologi namun lebih individualistik. Dalam kesehariannya anak-anak menghabiskan waktu untuk mengakses internet selama tiga sampai lima jam sehari sehingga memengaruhi karakter dan pola hidup mereka (Mahardika, 2017: 16).

Cogan \& Dericott (1998: 7) mengidentifikasi ada beberapa permasalahan global yang dihadapi oleh negara-negara di seluruh dunia. Budaya yang berasal dari luar dapat memengaruhi suatu bangsa melalui informasi yang begitu masif baik lewat media elektronik, cetak, televisi, dan media social. Budaya asing yang masuk tanpa adanya filter yang baik, lambat laun akan mengikis dan menghilangkan jati diri suatu bangsa.

Arus globalisasi, modernisasi dan ketatnya puritanisme dapat mengakibatkan terkikisnya rasa kecintaan terhadap budaya lokal. Sehingga kebudayaan lokal yang merupakan warisan leluhur bangsa akan tergeser oleh budaya asing, tereliminasi dan seakan tidak dipedulikan lagi oleh para pewarisnya.

Menghadapi perubahan sosial yang begitu pesat di era globalisasi ini. Pendidikan memiliki posisi yang strategis karena pendidikan mampu menjadi energi besar yang dapat menjadi filter sekaligus memberikan perubahan serta menjadi penghubung untuk mewariskan budaya dari generasi masa lalu kepada generasi saat ini dan generasi mendatang. Pendidikan juga dipandang sebagai lokomotif perubahan sosial dan peradaban masa depan masyarakat bangsa. Dengan demikian maka diharapkan pendidikan harus mampu mengakomodasi berbagai ide dan fenomena sosial yang berkembang sehingga pada giliranya semua persoalan bangsa bisa tertata secara baik. Diantara sekian banyak tantangan global peradaban masa depan, diskursusdiskursus tentang multikulturalisme terus dilakukan (Tilaar, 2004: 03). Keadaan bangsa Indonesia yang majemuk telah memberikan kesadaran akan pentingnya pemahaman multikulturalisme. Maka dari itu keberagaman yang merupakan identitas bangsa Indonesia harus menjadi kekuatan yang mampu mengintegrasikan dalam berbagai hal positif. Dalam hal inilah kurikulum pendidikan sejarah yang dikembangkan haruslah memperhitungkan dan mengakomodasi berbagai kepentingan serta kebutuhan masyarakat lokal yang terjewantahkan dalam apa yang dinamakan kearifan lokal sebagai penyangga utama multikulturalisme. Karena hanya dengan cara inilah berbagai gesekan yang berujung pada konflik sosial dan pertentangan kepentingan sebagai akibat dari keberagaman yang salah dikelolah bisa diminimalisir.

Fenomena yang terjadi belakangan ini, yang diakibatkan oleh perkembangan global yang begitu pesat telah menjadi tantangan untuk mengintegrasikan nilai-nilai kearifan lokal sebagai sebuah entitas masyarakat lokal dan nilai-nilai modernisasi sebagai entitas masyarakat global yang sangat bersinggungan dan begitu sulit untuk disatukan (Ufie n.d: 48-49).

Faktor global yang membawa pergeseran nilai-nilai budaya dan sosial juga mempengaruhi pola tindakan yang dilakukan generasi muda saat ini (Atmaja, dkk, 2017: 01). Di sinilah kearifan lokal menjadi relevan dan penting. Sebuah bangsa yang besar 
dan terhormat adalah bangsa yang memilki identitas dan jati dirinya (Afiqoh dkk, 2018: 43).

Pilihan untuk mengintegrasikan nilai-nilai multikultural berbasis kearifan lokal Sunda silih asah, silih asih, silih asuh dalam pembelajaran sejarah menjadi penting sejalan dengan semangat pendidikan sejarah yang terungkap dalam kurikulum pendidikan sejarah, bahwa dalam pembelajaran siswa tidak sebagai objek yang hanya dituntut untuk menyerap berbagai informasi yang diberikan guru, tetapi menjadi subjek belajar yang memiliki keluasan untuk mengoptimalkan berbagai kemampuan yang dimiliki untuk dapat dikembangkan (Ufie n.d: 49).

Seperti yang dinyatakan oleh Musadad dan Wasino (2012) bahwa dari segi pembangunan bangsa, pembelajaran sejarah mempunyai arti yang sangat penting. Hal ini terkait dengan pentingnya hubungan antara sejarah dan pendidikan, nilai sejarah semakin punya kekuatan untuk menumbuhkan sifat, watak, dan kemampuan yang diinginkan (Musadad \& Wasino, 2012: 227). Dengan belajar sejarah anak didik diharapkan menjadi manusia yang demokratis, tolerasi, mampu menebar cinta kasih, arif dan bijaksana.

Dengan demikian mengintegrasikan nilai-nilai keberagaman berbasis kearifan lokal Sunda dalam pembelajaran sejarah patut dilaksanakan dalam rangka membentuk sikap dan karakter siswa sehingga melalui para siswa nilai-nilai keberagaman, toleransi, rasa kebangsaan dan silih asah, silih asih, silih asuh yang hidup dan berkembang di tengah masyarakat yang diyakini memiliki kekuatan dalam menyatukan segala bentuk perbedaan serta merekatkan kohesi sosial pada masyatakat lokal yang merupakan wujud konkrit dari kearifan lokal dapat terwujud.

\section{TEORI DAN METODOLOGI}

\section{Landasan Teoritis}

1. Multikulturalisme

Akar kata multikulturalisme adalah kebudayaan. Secara etimologis multikulturalisme dibentuk dari kata multi (banyak), kultur (budaya), dan isme (aliran/paham). Secara hakiki dalam kata itu terkandung pengakuan akan martabat manusia yang hidup dalam komunitasnya dengan kebudayaannya masing-masing yang unik (Wasino, 2011: 11). Konsep multikulturalisme tidaklah dapat disamakan dengan konsep keanekaragaman secara suku bangsa atau kebudayaan saja yang menjadi ciri masyarakat majemuk, karena multikulturalisme menekankan keanekaragaman kebudayaan dalam kesederajatan atau kesetaraan budaya (Mahfud, 2016: 75).

Multikulturalisme merupakan institusionalisasi dari keanekaragam kebudayaan yang dimiliki oleh kelompok-kelompok etnis di dalam suatu nation state (Tilaar, 2004: 84) ini artinya bahwa multikulturalisme merupakan suatau paham yang menyakini bahwa perbedaan dan keberagaman dalam suatu budaya memiliki nilai kebersamaan.

Selanjutnya menurut Blum (2001) multikulturalisme adalah pemahaman, penghargaan dan penilaian atas budaya seseorang, dan sebuah penghormatan dan keingintahuan tentang budaya etnis orang lain. la meliputi sebuah penilaian terhadap kebudayaan-kebudayaan orang lain, bukan dalam arti menyetujui seluruh aspek dari kebudayaan-kebudayaan tersebut, melainkan mencoba melihat bagaimana kebudayaan tertentu dapat mengekspresikan nilai bagi anggota-anggotanya sendiri (Blum, A. Lawrence 2001: 16).

Menurut Parekh (2001), ada tiga komponen multikulturalisme, yakni kebudayaan, pluralitas kebudayaan, dan cara tertentu untuk merespons pluralitas itu. Artinya multikulturalisme bukanlah doktrin politik pragmatik, melainkan cara pandang kehidupan manusia. Karena hampir semua negara di dunia tersusun dari aneka ragam kebudayaan.

2. Kearifan Lokal 
Kearifan lokal (local wisdom) terdiri dari dua kata: kearifan (wisdom) dan lokal (local). Local berarti setempat, sedangkan wisdom sama dengan kebijaksanaan. Secara umum, maka local wisdom (kearifan setempat) dapat dipahami sebagai gagasangagasan setempat (local) yang bersifat bijaksana, penuh kearifan, bernilai baik, yang tertanam dan diikuti oleh anggota masyarakatnya (Sartini, 2009: 111).

Soebadio mengatakan bahwa local genius adalah juga cultural identity, identitas/kepribadian budaya bangsa yang menyebabkan bangsa tersebut mampu menyerap dan mengolah kebudayaan asing sesuai watak dan kemampuan sendiri (Kusmintayu, 2014: 31).

Sementara Moendardjito mengatakan bahwa unsur budaya daerah potensial sebagai local genius karena telah teruji kemampuannya untuk bertahan sampai sekarang. Ciri-cirinya adalah: (1) mampu bertahan terhadap budaya luar; (2) memiliki kemampuan mengakomodasi unsur-unsur budaya luar; (3) mempunyai kemampuan mengintegrasikan unsur budaya luar ke dalam budaya asli; (4) mempunyai kemampuan mengendalikan; dan (5) mampu memberi arah pada perkembangan budaya (Sartini, 2009: 111).

Hal ini sejalan dengan apa yang dijelaskan oleh Rosidi (2011) bahwa kearifan local merupakan kemampuan kebudayaan setempat dalam menghadapi pengaruh kebudayaan asing pada waktu kedua kebudayaan berhubungan (Rosidi, 2011). Sehingga dapat dikatakan bahwa kearifan local merupakan identitas budaya suatu masyarakat yang mampu menyerap dan mengakomodasi serta mengintegrasikan budaya luar dengan budaya asli, sehingga mampu memberi arah terhadap perkembangan budaya dan kehidupan manusia.

Semangat atau karakter falsafah Sunda silih asah, silih asih, silih asuh bisa dijadikan salah satu alternatif. Karena akan berkontribusi pada pembentukan kondisi masyarakat yang mempunyai karakter/jati diri, memberikan arah untuk saling menyemangati, menebar cinta kasih dan saling menjaga dalam hal ini saling hargamenghargai antar sesama manusia sehingga dapat meningkatkan kualitas kehidupan kemanusiaannya.

3. Pembelajaran Sejarah

Pembelajaran sejarah menurut Latif (2006: 99) merupakan suatu aktifitas belajar mengajar yang dilakukan oleh pendidik dengan cara menjelaskan pada siswa tentang gambaran kehidupan masyarakat masa lampau yang menyangkut peristiwa-peristiwa penting dan memiliki arti khusus. Sejarah digambarkan sebagai masa lalu manusia dan seputarnya yang disusun secara ilmiah dan lengkap meliputi urutan fakta masa tersebut dengan tafsiran dan penjelasan yang memberi pengertian kefahaman tentang apa yang berlaku.

Susanto (2014: 06) juga menjelaskan mengenai korelasi pendidikan seajrah dan penguatan pendidika karakter yaitu pendidikan seajarah yang memiliki informasi mengenai identitas ke-Indonesiaan perlu direvitalisasi dan reaktualisasi melalui budaya lokal agar bangsa Indonesia memiliki "rasa hayat historis" dan karakter bangsa yang kuat. Pendidikan yang berpijak pada budaya lokal dan bercermin pada sejarah akan mampu menghasilkan generasi yang memiliki karakter yang kuat, menjadi suatu yang penting untuk menggali nilai-nilai sejarah dan budaya lokal guna menemukan akar solusi pemecahan berbagai masalah sosial dalam masyarakat dewasa ini.

Peristiwa-peristiwa sejarah akan diproses oleh siswa untuk menjadikan suatu pengetahuan menjadi milik dirinya dan pada akhirnya akan mempengaruhi proses berpikir dan bertindak dengan menghayati sebuah peristiwa hingga akhirnya siswa tersebut berhasil menemukan makna yang terkadung di dalamnya. Proses ini berkaitan dengan Pembelajaran sejarah yang merupakan cabang ilmu pengetahuan yang dapat digunakan untuk melatih kecerdasan, membentuk sikap, watak dan kepribadian peserta didik (Zahro, Sumardi, \& Marjono, 2017: 4-5). 
Pembelajaran sejarah memiliki sasaran untuk membuat masyarakat mampu mengevaluasi nilai-nilai dan hasil yang telah dicapai oleh generasinya, membantu mencari jalan keluar bagi berbagai masalah sosial dan perseorangan, mengajarkan prinsip-prinsip moral, dan menanamkan orientasi ke depan (Kochar, 2008: 31). Dengan demikian bahwa pembelajaran sejarah tidak hanya mengedepankan pengetahuan tetapi di dalamnya syarat akan nilai dan moral yang dapat diterapkan di kehidupan sehari-hari.

\section{METODE PENELITIAN}

Dalam penulisan artikel ini menggunakan metode deskriptif kualitatif dengan pendekatan studi kepustakaan atau library research. Riset kepustakaan merupakan serangkaian kegiatan yang dilakukan berkenaan dengan metode pengumpulan data yang diambil dari berbagai pustaka, kemudian dilanjutkan dengan membaca secara cermat dan mencatat bahan-bahan yang relevan dengan tema, serta mengolah bahan penelitian tersebut (Zed, 2004: 54).

Riset pustaka yang dilakukan untuk mencari data dan informasi membatasi pada literatur atau bahan-bahan seperti buku, artikel, jurnal, surat kabar, laporan badan penelitian, dan sumber kepustakan lain yang relevan serta berhubungan dengan multikulturalisme dan kearifan local Sunda slih asah, silih asih, silih asuh. Data atau informasi yang telah diperoleh, selanjutnya akan disusun berdasarkan hasil studi literatur yang sesuai dan dapat dipertanggungjawabkan, Analisis data dalam artikel terdiri dari dua tahap yaitu proses reduksi data dan penyajian data. Reduksi data dilakukan untuk mempermudah penulis memilih data dari literatur dengan valid, sedangkan penyajian data dilakukan untuk penulis memberikan simpulan dari hasil pembahasan.

\section{Konsep Pendidikan Multikulturalisme}

\section{HASIL DAN PEMBAHASAN}

Dalam sejarahnya multikulturalisme semula merupakan perjuangan politik dari migran kulit hitam dari Afrika di Amerika untuk menununtut persamaan hak (Wasino, 2011: 06), termasuk tuntutan persamaan hak dalam pendidikan.

Sebagai sebuah ide, pendidikan multikultural dibahas dan diwacanakan pertama kali di Amerika dan negara-negara Eropa Barat pada tahun 1960-an oleh gerakan yang menuntut diperhatikannya hak-hak sipil (civil right movement). Tujuan utama dari gerakan ini adalah untuk mengurangi praktik driskriminasi yang dilakukan oleh kelompok mayoritas terhadap kelompok minoritas (Suparlan, 2002: 2-3).

Menurut Banks (1995;2) pendidikan multikultural menekankan pada kesederajatan dalam kesempatan pendidikan kepada masyarakat dan memasukkan seluruh partisipasi siswa dalam berbagai hal (Ufie n.d: 55). la juga menegaskan bahwa pendidikan multikultural berarti ide, gerakan, pembaharuan pendidikan dan proses pendidikan yang tujuan utamanya adalah untuk mengubah struktur lembaga pendidikan supaya peserta didik baik pria maupun wanita, peserta didik berkebutuhan khusus, dan peserta didik yang merupakan anggota dari kelompok ras, etnis, dan kultur yang bermacam-macam itu akan memiliki kesempatan yang sama untuk mencapai prestasi akademis di sekolah (Ibrahim, 2008: 121).

Paul C. Gorski (2010) juga menjelaskan bahwa pendidikan multikulturalisme adalah dalam rangka memberikan pengalaman pendidikan yang memungkinkan semua peserta didik mengembangkan sepenuh-penuhnya seluruh potensi dirinya, dan menjadi anggota masyarakat yang sadar sosial dan berperan aktif secara lokal, nasional, dan juga global (Amirin, 2012: 04). Sehingga dengan adanya kesadaran tersebut, peserta didik akan lebih terbuka dan menerima setiap perbedaan yang ada baik dalam lingkup local bahkan hingga lingkup yang jauh lebih luas (global). 
Gorski merumuskan tiga tujuan utama pendidikan multikultural, yaitu: 1) meniadakan diskriminasi pendidikan, memberi peluang sama bagi setiap anak untuk mengembangkan potensinya; 2) menjadikan anak bisa mencapai prestasi akademik sesuai potensinya; 3) menjadikan anak sadar sosial dan aktif sebagai warga masyarakat lokal, nasional, dan global (Lionar \& Mulyana, 2019: 15).

Dengan demikian, dapat dikatakan pendidikan multikultural adalah sistem dan cara meningkatkan kualitas hidup manusia dalam segala aspek kehidupannya tanpa membedakan ras, etnik, agama dan strata sosial.

Selanjutnya Tilaar (2004: 59) menjelaskan bahwa pendidikan multikulturalisme mempunyai ciri-ciri sebagai berikut: (1) Tujuanya membentuk "manusia budaya" dan menciptakan "masyarakat berbudaya (berperadaban)". (2) Materinya mengajarkan nilainilai luhur kemanusian, nilai-nilai bangsa, dan nilai-nilai kelompok etnis (cultural). (3) Metodenya demokratis, yang menghargai aspek-aspek perbedaan dan keberagaman budaya bangsa dan kelompok etnis (multikulturalis). (4) Evaluasinya ditentukan pada penilaian terhadap tingkah laku anak didik yang meliputi persepsi, apresiasi, dan tindakan terhadap budaya lainnya.

Dalam konteks ini dapat dikatakan, tujuan utama dari pendidikan multikultural adalah untuk menanamkan sikap simpati, respek, apresiasi, saling memberikan dorongan/dukungan, saling menyayangi, saling membimbing dengan sesama dan empati terhadap setiap perbedaan yang ada.

Maka dari itu lembaga pendidikan kita haruslah mengembangkan pendidikannya berdasar pada konsep pengembangan nlai-nilai multikultural yang terakomodir dalam pembelajaran sejarah. Karena hingga saat ini dalam pendidikan di Indonesia belum ada mata pelajaran multikulturalisme. Sehingga dengan demikian konsep pendidikan multikulturalisme yang merupakan manifestasi dari keragaman budaya yang didalamnya menyangkut adanya tradisi dan kearifan local dapat dikembangakan melalui mata pelajaran yang sekiranya relevan dengan konsep multikulturalisme.

Konsep multikulturalisme yang berbasis pada kearifan local bukanlah suatu konsep yang kosong, yang terus-terusan dibicarakan disaat adanya berbagai gejolak yang menimpa keberagaman kita. Akan tetapi konsep ini hendaknya dimanifestasikan dalam berbagai bidang kehidupan kita terutama melalui pendidikan, karena pendidikan merupakan tempat yang paling tepat untuk membumikan nilai multicultural yang berbasiskan kearifan local.

\section{Konsep Nilai Kearifan Lokal Sunda Silih Asah, Silih Asih, Silih Asuh}

Kearifan lokal Indonesia merupakan kekayaan bangsa yang seharusnya dilestarikan dan dipertahankan keberadaannya. Keberlanjutan atau kelestarian kearifan lokal ini dapat terjadi atau dilakukan melalui proses pendidikan dan pembelajaran. Sehingga kearifan lokal ini dapat diteruskan dari satu generasi ke generasi selanjutnya. Menurut Saini (2005) kearifan lokal adalah sikap, pandangan, dan kemampuan masyarakat dalam mengelola lingkungan rohani dan jasmaninya, yang memberikan kepada komunitas itu daya tahan dan daya tumbuh di dalam wilayah dimana komunitas itu berada (Ufie n.d: 53). Dengan kata lain kearifan lokal adalah jawaban kreatif terhadap situasi yang terjadi di dalam masyarakat. Umumnya kearifan local merupakan pandangan hidup yang dijadikan sebagai pedoman untuk menjalin kehidupan yang harmoni di anatar masyarakat pendukung suatu kebudayaan.

Dalam kehidupan masyarakat Sunda sendiri terdapat kearifan budaya yang meletakkan pentingnya keharmonisan hubungan antarmanusia dalam kehidupan masyarakatnya yang saling ketergantungan dengan tidak melupakan jati-diri dan habitatnya masing-masing, yang bertujuan untuk meningkatkan kualitas kemanusiaan. Kearifan budaya tersebut terdapat dalam konsep silih asah, silih asih, silih asuh yang mengandung nilai moral kebaikan dalam membangun kebersamaan melalui kehidupan masyarakatnya. 
Esensi dari falsafah kehidupan masyarakat Sunda adalah meletakkan pentingnya keharmonisan hubungan antar manusia dan masyarakat yang saling membutuhkan (interdependency) satu dengan yang lainnya dengan tidak melupakan jati diri dan habitatnya masing-masing, hal tersebut merupakan kesadaran yang harus dibangun bagi para anggota masyarakatnya (Suryalaga, 2010: 126). Silih asih, silih asah, silih asuh merupakan landasan nilai dalam membangun kebersamaan kehidupan masyarakat Sunda untuk meningkatkan kualitas hidupnya supaya menjadi manusiamanusia yang lebih beradap, saling menebar cinta kasih, saling membimbing dan hargamenghargai.

Makna yang terkandung dalam falsafah Sunda tersebut mengandung nilai-nilai kebersamaan yang saling ketergantungan dalam kehidupan bermasyarakat, yang secara tradisi telah tertanam melalui kebudayaannya. Silih asih dimaknai sebagai saling mengasihi dengan segenap kebeningan hati. Silih asah bermakna saling mencerdaskan kualitas kemanusiaan. Silih asuh tak pelak lagi dimaknai kehidupan yang penuh harmoni dan cinta kasih (Suryalaga, 2010: 106). Orientasi dari konsep nilai yang terkandung di dalamnya ternyata dapat dimaknai sebagai proses pemberdayaan masyarakat dalam menumbuhkan keberdayaan individu dalam kehidupan bermasyarakat yang berfungsi untuk mencapai kualitas kemanusian agar berharkat dan bermartabat.

Kearifan lokal tersebut dalam suatu komunitas masyarakat memegang peranan penting untuk pengendalian dan memberikan arah terhadap perkembangan kebudayaan masyarakat tersebut. Karena kebudayaan dapat diartikan sebagai seluruh usaha dan hasil usaha manusia dan masyarakat untuk mencukupi segala kebutuhan serta hasratnya untuk memperbaiki nasib hidupnya (Poespowadjo, 2011: 275). Dalam kebudayaan inilah teridentifikasi dan termanifestasi kepribadian suatu masyarakat yang tercermin dalam orientasi yang menunjukkan pandangan hidup serta sistem nilai dalam persepsi untuk melihat dan menanggapi dunia luarnya, sehingga pola serta sikap hidup yang diwujudkan dalam tingkah-laku sehari-hari melalui gaya hidup yang mewarnai kehidupannya.

Dari pemahaman falsafah sunda tersebut menjelaskan bahwa posisi budaya lokal seperti budaya Sunda yang diwakili oleh silih asih, silih asah dan silih asuh memiliki posisi sebagai sebuah pendekatan yang berwawasan integratif kebangsaan, sekaligus penanaman akan sebuah keharmonisan hubungan sosial antar sesama yang dibangun dari sisi nurani individu.

Sehingga, penting sekali falsafah kearifan local Sunda ini di delivery kepada setiap insan manusia tidak hanya masyarakat Sunda melalui dunia pendidikan. Agar falsafah yang dibangun dari sisi nurani ini, dapat tersampaikan dengan baik, hadir dalam setiap nurani indvidu dengan penuh penghayatan, sehingga mampu menghasilkan generasi yang penuh cinta kasih, cerdas, demokratis penuh toleransi dan berjiwa kemanusiaan.

\section{Integrasi Nilai Multikultural Berbasi Kearifan Lokal Sunda Silih Asah, Silih Asih, Silih Asuh dalam Pembelajaran Sejarah}

Berbicara mengenai paradigma pendidikan, kita dapat menyimpulkan betapa pentingnya mengenyam suatu pendidikan dalam kehidupan. Karena melalui pendidikan seseorang dapat mengembangkan pengetahuan, wawasan, nilai dan karakter bahkan sebagai upaya pewarisan kebudayaan, selain itu lebih luas lagi apabila ingin menilai kualitas suatu bangsa dapat dilihat dari kualitas pendidikan di negara tersebut.

Kurikulum dapat dipandang sebagai suatu rancangan pendidikan. Sebagai suatu rancangan, kurikulum menentukan pelaksanaan dan hasil pendidikan. Pendidikan merupakan usaha mempersiapkan peserta didik untuk terjun ke lingkungan masyarakat. Pendidikan bukan hanya untuk pendidikan semata, namun memberikan bekal pengetahuan, keterampilan serta nilai-nilai untuk hidup, bekerja dan mencapai perkembangan lebih lanjut di masyarakat. Peserta didik berasal dari masyarakat, 
mendapatkan pendidikan baik formal maupun informal dalam lingkungan masyarakat dan diarahkan untuk kehidupan masyarakat pula (Rosni, 2017: 129).

Kehidupan masyarakat, dengan segala karakteristik dan kekayaan budayanya menjadi landasan dan sekaligus acuan bagi pendidikan. Dewasa ini para ahli pendidikan dan kurikulum telah menempatkan sosial budaya sebagai salah satu landasan penting dalam pengembangan kurikulum

Sebagai bangsa yang berbudaya, tentunya ini menjadi hal yang sangat penting untuk diterapkan dalam pendidikan kita. Sehingga dengan demikian pengembangan kurikulum dalam setiap jenjang pendidikan haruslah memperhatikan keragaman budaya yang ada di masyarakat. Konsep mulitkulturalisme yang berbasis kearifan local Sunda silih asah, silih asih, silih asuh sudah semestinya dapat dijadikan sebagai salah satu landasan social budaya dalam pengembangan kurikulum sejarah yang mengandung nilai demokratis, humanis, toleransi, cinta kasih, saling membimbing, dan melindungi.

Hasan (2012: 108) menjelaskan bahwa pendekatan multikultural dalam kurikulum sejarah harus mengakomodasi perbedaan kultural peserta didik, memanfaatkan kebudayaan itu sebagai sumber konten dan sebagai titik berangkat untuk pengembangan kebudayaan, pemahaman terhadap kebudayaan orang lain, toleransi, membangkitkan semangat kebangsaan berdasarkan Bhineka Tunggal Ika, mengembangkan prilaku yang etis dan dapat memanfaatkan kebudayaan pribadi sebagai bagian dari entry behavior siswa sehingga dapat menciptakan kesempatan yang sama bagi siswa untuk berprestasi.

Dalam falsafah Sunda, kata silih berarti saling, mengandung makna nilai transformasi yang bersifat resiprokal dan saling memberikan respon dengan penuh kesantunan. Kata asih berarti cinta, mengandung makna nilai ontologis bahwa keberadaan 'asih' berasal dari Tuhan Yang Maha Pengasih, sehingga nilai asih menjadi landasan kehidupan dalam membangun keharmonisan hidup manusia. Kata asah berarti menajamkan, mengandung makna nilai epistemologi bahwa kemampuan mengasah akal, rasa, dan karsa dalam diri manusia akan menghasilkan pengetahuan dan ilmu pengetahuan dalam kehidupannya. Kata asuh berarti membimbing, mengandung makna nilai aksiologi bahwa dalam membangun hubungan silaturahmi didasari atas saling menghargai kewajiban dan hak asasi manusia berlandaskan pada nilai-nilai keharmonisan dalam membangun kualitas kemanusiaan (Saleh, dkk, 2013: 161).

Integrasi nilai multicultural berbasis kearifan local Sunda silih asah, silih asih, silih asuh menjadikan makna transformasi nilai yang bersumber dari konsep multi culture dan subtansi makna nilai asih, asah, asuh dalam kehidupan antar manusia dalam realitas kehidupan masyarakat, akan membangun harmonisasi yang saling ketergantungan untuk meningkatkan kualitas kemanusiaan.

Secara konkrit prinsip-prinsip atau nilai-nilai itu haruslah diterjemahkan dalam pembelajaran oleh guru mata pelajaran sejarah melalui silabus dan RPP sebagai pedoman operasional pembelajaran di kelas. Guru hendaknya mampu menerjehmakan nilai-nilai multikultural yang berbasis kearifan local Sunda silih asah, silih asih, silih asuh secara lebih konkrit dalam materi pembelajaran sejarah.

Konsep multicultural yang sudah menjadi identitas bangsa kita yang terdiri dari bermacam suku bangsa tentunya harus menjadi landasan kuat dalam kurikulum pembelajaran sejarah. Sehingga nantinya akan menumbuhkan sikap tenggang rasa antar siswa, tolong menolong, menghilangkan perasaan minder antara siswa miskin dan kaya, menghormati perbedaan, toleransi, saling menghormati dan sebagainya. Dalam konteks kelokalan maka filosofi budaya Sunda silih asah, silih asih, silih asuh, yang telah menjadi kekuatan, semangat, pengikat serta penuntun kehidupan bersama masyarakat lokal harus juga menjadi sumber dalam pembelajaran sejarah.

Jika hal ini dapat diterapkan dengan baik, maka akan menjadi suatu keniscayaan bahwa pembelajaran sejarah bukan hanya sekedar transfer of knowledge tetapi juga 
transfer of value artinya bahwa bukan sekedar membelajarkan siswa menjadi cerdas, tetapi juga berakhlak mulia (Ufie n.d: 57).

Hal ini sesuai dengan esensi dari kurikulum 2013 yang mana tidak hanya bertujuan untuk meningkatkan pengetahuan peserta didik saja, tetapi juga membekali peserta didik dengan keterampilan serta karakter luhur sesuai kepribadian bangsa Indonesia (Shufa, 2018: 49).

Upaya untuk mengintegrasikan nilai-nilai multikultural berbasis kearifan lokal di dalam kurikulum sejarah sangat diperlukan untuk mengurangi berbagai prasangka di dalam perlakuan dan tingkah laku rasial dari etnis-etnis tertentu ataupun perlakuan menyimpang dari siswa-siswa tersebut.

Yang terpenting dalam hal ini adalah mengintegrasikan muatan nilai-nilai yang terkandung dalam multikultur dan kearifan lokal kedalam mata pelajaran sejarah melalui kegiatan pembelajran haruslah dapat diterapkan dan tercermin dalam kehidupan peserta didik. Selain itu, pengintegrasian pendidikan multikultur berbasis kearifan lokla harus dilakukan dan terlihat dalam aktivitas seluruh warga sekolah maupun dalam manajemen sekolah secara umum (Depdiknas, 2003).

\section{KESIMPULAN}

Indonesia sebagai suatu negara multicultural terbesar di dunia dan Sunda sebagai salah satu suku terbesar di Indonesia tentunya harus menjadi pondasi utama untuk menopang berbagai kergaman yang ada. Konsep multikulturalisme yang mengandung nilai demokratis, pluralistik, humanis serta toleransi, serta falsafah Sunda silih asah, silih asih, silih asuh yang mengandung nilai moral kebaikan dalam kehidupan masyarakat Sunda masa lalu hingga kini yang menjadi pedoman dan pandangan hidup masyarakat, yang muncul dalam wujud budaya dan unsur-unsur kebudayannya. Nilai moral kebaikan yang telah lama menjadi pandangan hidup dan membangun kebersamaan untuk meningkatkan kualitas kemanusiaan pada kehidupan masyarakatnya sudah saatnya untuk diwariskan kepada generasi muda bangsa ini melalui pendidikan.

Konsep mengembangkan nilai-nilai multikultural berbasis kearifan local Sunda silih asah, silih asih, silih asuh melalui pendidikan dengan mengintegrasikan dalam materi pembelajaran sejarah sebagaimana yang diinginkan oleh kurikulum merupakan hal penting yang patut dilaksnakan sehingga konsep multikulturalisme dan kearifan lokal bukan hanya sebagai slogan semata namun dapat direalisasikan. Dengan demikian maka iklim kebersamaan, dalam tata pergaulan yang lebih demokratis, humanis, toleran dan etis demi Indonesia yang kita cintai dapat dijumpai dimana-mana.

\section{DAFTAR PUSTAKA}

Afiqoh, Noviana, Hamdan Tri Atmaja, and Ufi Saraswati. 2018. "Penanaman Nilai Kearifan Lokal Dalam Pembelajaran Sejarah Pokok Bahasan Perkembangan Islam Di Indonesia Pada Siswa Kelas X IPS Di SMA Negeri 1 Pamotan Tahun Ajaran 2017 / 2018." Indonesian Journal of History Education 6 (1): 42-53.

Amirin, Tatang M. 2012. "Implementasi Pendekatan Pendidikan Multikultural Kontekstual Berbasis Kearifan Lokal Di Indonesia." Jurnal Pembangunan Pendidikan: Fondasi Dan Aplikasi 1 (1): 1-16.

Atmaja, Hamdan Tri, and dkk. 2017. "Konstruksi Pembelajaran IPS Berbasis KebangSaan (Studi Fenomenalogi Pada Guru Pendidikan IPS) Pada Seminar Ta-Hunan Pendidikan IImu-IImu Sosial." Universitas Negeri Medan.

Blum. A. Lawrence. 2001. Antirasisme, Multikulturalisme Dan Komunitas Antar Ras, Tiga Nilai Yang Bersifat Mendidik Bagi Sebuah Masyarakat Multikultural, Dalam Larry May Dan Shari Collins Chobanian, Etika Terapan: Sebuah Pendekatan Mutikultural, Terjemahan: Sinta Carolina Dan Dad. Yogyakarta: Tiara Wacana. 
Cogan, J. J, and Dericott. 1998. Citizenship Education For The 21st Century: Setting The Contexs. London: Kogan Page.

Depdiknas. 2003. Undang-Undang No. 20 Tahun 2003, Sistem Pendidikan Nasional. www.depdiknas.go.id.

Hasan, Said Hamid. 2012. Pendidikan Sejarah Indonesia, Isu Dalam Ide Dan Pembelajaran. Bandung: Rizqi Press.

Ibrahim, Ruslan. 2008. "Pendidikan Multikultural: Upaya Meminimalisir Konflik." Jurnal El-Tarbaw 1 (1): 112-27.

Kochar. 2008. Pembelajaran Sejarah. Jakarta: Grasindo.

Kusmintayu, Norma. 2014. "Upacara Tradisional Sedekah Laut Di Kabupaten Cilacap (Tinjauan Makna, Kearifan Lokal, Dan Relevansinya Dengan Pembelajaran Bahasa Indonesia Di SMA/SMK)." Tesis. Surakarta. Universitas Sebelas Maret: [tidak diterbitkan].

Latif, J.A. 2006. Manusia Filsafat Dan Sejarah. Jakarta: Bumi Aksara.

Lionar, Uun, and Agus Mulyana. 2019. "Nilai-Nilai Multikultural Dalam Pembelajaran Sejarah: Identifikasi Pada Silabus." IJSSE: Indonesian Journal of Social Science Education Volume 1 (1): 11-25.

Mahardika, Alhafizh. 2017. "Penanaman Karakter Bangsa Berbasis Kearifan Lokal Di Sekolah." Jurnal Pendidikan Kewarganegaraan 7 (2): 16-27.

Mahfud, Choerul. 2016. Pendidikan Mutikultural. Yogyakarta: Pustaka Pelajar.

Musadad, Akhmad Arif, and Wasino. 2012. "Model Pelatihan IPS-Sejarah Berbasis

Pendidikan Multikultural." Paramita 22 (2): 227.

Parekh, Bikhu. 2001. Rethinking Multiculturalism. Cambridge: Harvard.

Poespowadjo. 2011. Kearifan Lokal Dalam Perspektif Budaya Sunda. Bandung: PT. Kiblat Buku Utama.

Rosidi, Ajip. 2011. Kearifan Lokal Dalam Perspektif Budaya Sunda. Bandung: Kiblat Buku Utama.

Rosni. 2017. "Landasan Sosial Budaya Dan Perkembangan IImu Pengetahuan Dalam Pengembangan Kurikulum" VI (1): 128-36.

Saleh, Firdaus, Soedjati, and Lasiyo. 2013. "Makna 'Silas' Menurut Kearifan Budaya Sunda Perspektif Filsafat Nilai Relevansinya Bagi Pemberdayaan Masyarakat Miskin." Sosiohumaniora 15 (2): 158-66.

Sartini, W.N. 2009. "Menggali Nilai Kearifan Lokal Budaya Jawa Lewat Ungkapan (Bebasan, Saloka Dan Paribasa." Jurnal Ilmiah Bahasa Dan Sastra 5 (1): 111-20. Shufa, Naela Khusna Faela. 2018. "Pembelajaran Berbasis Kearifan Lokal Di Sekolah

Dasar: Sebuah Kerangka Konseptual." Inopendas Jurnal IImiah Kependidikan 1 (1): 48-53.

Suparlan, Parsudi. 2002. "Kesetaraan Warga Dan Hak Budaya Komuniti Dalam Masyarakat Majemuk Indonesia." Jurnal Antropologi Indonesia 6.

Suryalaga, H.R. Hidayat. 2010. Kasundaan Rawayan Jati. Bandung: Yayasan Nur Hidayah.

Susanto, Heri. 2014. Seputar Pembelajaran Sejarah (Isu, Gagasan Dan Strategi Pembelajaran). Yogyakarta: Aswaja Pressindo.

Tilaar, H.A.R. 2004a. Multikulturalisme Tantangan-Tantangan Global Masa Depan Dalam Transformsi Pendidikan Nasional. Jakarta: Grasindo.

_. 2004. Paradigma Baru Pendidikan Nasional. Jakarta: Rineka Cipta.

Ufie, Agustinus. n.d. "Mengintegrasikan Nilai-Nilai Multikulturalisme Berbasis Kearifan Lokal Sebagai Sumber Pembelajaran Sejarah." Universitas Pattimura, 47-61.

Wasino. 2011. "Multikulturalisme Dalam Perspektif Sejarah Sosial." Seminar Multikulturalisme Dan Integrasi Bangsa Dalam Pembangunan Kebudayaan Dan Pariwisata (Kementerian Kebudayaan Dan Pariwisata), 2011.

Zahro, Mustika, Sumardi, and Marjono. 2017. "Jurnal Historica." JJurnal Historica 1 (1): 
$1-11$.

Zed, Mestika. 2004. Metode Penelitian Kepustakaan. Jakarta: PT Raja Grafindo Persada. 